\title{
Measuring the Impact of Blended Learning in EFL Classroom
}

\author{
Sayid Ma'rifatulloh \\ Universitas Hasyim Asy'ari, Jombang, Indonesia \\ \{sayid.unhasy@gmail.com\}
}

\begin{abstract}
The influence of the 4.0 Industrial Revolution in education practice has a significant impact on students learning process both in and outside classroom, so that teachers and students are expected to be able to adapt the changes. This study aims to explore the extent to which the impact of blended learning on the students' writing skills. This study used mixed method where the quasi-experimental design is combined with qualitative data collected from the field notes. The data are taken from the results of the students pretest and posttest, as well as the field notes during the treatment. The data in the form scores are analyzed using T-test, while then it is analyzed deeper and compared to the field notes. The study was conducted in one Islamic university in Indonesia, Universitas Hasyim Asy'ari, consisting of two classes with approximately 35 students in each. The results showed that, although the average writing score of both classes increased, the results of the N-Gain and Ttest analysis showed no significant difference between the effectiveness of the conventional and the blended learning model. In other words, blended learning can be an alternative way in teaching writing.
\end{abstract}

Keywords: Blended Learning, Conventional Classroom, Writing Approach

\section{Introduction}

The history has proven that the industrial revolution has impacted greatly on human civilization from the first to the fourth era. In the era of industrial revolution 4.0, the advance of technology especially the internet has changed how the aspects of human life run such as industry, education, and social relation. In education sector, for example, the use of online learning is common nowadays, and it is considered as an effective way to deliver classroom instruction. Furthermore, distance learning is more impactful especially for adult learners due to the flexibility and adaptability in workforce [1]. Therefore, every education institution has a significant role to prepare the next generation to be ready to face global challenges by utilizing technology as well as possible.

Another impact of the distance learning in education is on the process of teaching learning becomes more student centered. More activities in exploring materials are conducted more freely by the students, and the teachers are inclined to be the facilitators during the process. The development of digital-based learning in educational institutions today has proven to have 
a positive impact on the outcomes. In addition, the use of the internet has impacted greatly on the way how the information is delivered such as the use of e-materials and the ease of finding online resources. Nowadays, digital libraries are ubiquitous; it is easy for students to find resources from the internet. Books that used to be printed now can be read simply by using digital tools, such as computers or cellphones. Millions of articles written on the internet, for instance, certainly play a big role in the development of human knowledge. Therefore, it is important to keep up with technological developments and make the best use of it in education environment.

In the context of Indonesian Education, especially in university level, the ability of students to utilize technology is a necessity. In the learning process, the use of e-Learning has gradually been used in educational institutions in Indonesia. E-book based learning resources, for example, have been widely used by Indonesian academics. Education practitioners (teachers and lecturers) in Indonesia are quite familiar with the use of digital slides, videos, or audio files to help them deliver learning materials. Indonesian government now takes a great focus on the use of digital improvement in Indonesian education system. The government has provided some online learning facilities such as rumahbelajar and kelasmaya that can be accessed by teachers and students online at https://belajar.kemdikbud.go.id/. Another online platform provided by the government is moodle-based platform that is called spada, it is used especially by Indonesian universities. Therefore, Indonesian academics now has started to use those online platforms, and one of the impact is the implementation of blended learning becomes more common [2].

Blended learning is a combination of online and offline learning models that is "open", where researchers or academics can create and innovate depends on their learning needs. According to Garrison and Vaughan [3], blended learning model includes at least the following elements: Integration between face-to-face and online learning; Learning design is based on optimizing student engagement; Restructuring of traditional classroom contacts and flexibility of time to online classrooms. Furthermore, Littlejohn and Pegler [4] exemplify several activities in blended learning, including: Access to various digital-based alternative sources; Online learning process with tutors as facilitators and Emphasis on collaborative creativity; Students can download content to computers and mobile devices, use podcasts and e-books as learning resources, as well as share notes in class, and can update lessons anytime and anywhere; Make use of online simulations to aid understanding in real life problem solving; The content provided is relevant to individual interests; The existence of a virtual learning environment; Online interactions and conferences; Keep in touch with peers away from the classroom through the use of instant messaging and other informal 'social computing' mechanisms; Compile and publish e-portfolios of the programs that have been studied; and Seamless integration of physical and virtual study spaces.

Blended learning is also considered as a preferred learning model with several advantages. According to MacDonald [5], several benefits of blended learning include: pragmatically, blended learning excels in terms of flexibility and asynchronous choices; Students and teachers can interact through both written interactions and video conferencing; In terms of effectiveness, blended learning provides a large selection of media and sources. In addition, the integration of synchronous and asynchronous activities can be an alternative solution for the wide range of student activities. Moreover, from a pedagogical perspective, blended learning can increase interaction and discussion between students and students and also students and teachers with video conferences.

From the characteristics of blended learning classes above, it can be understood that blended learning is not only a combination of online and offline classes, but aims to make 
students more active during their learning process because of the wider scope of learning and flexible time. Therefore, it is important to keep the ideas that blended learning is a flexible learning design and the challenge is to do things differently from the traditional way.

Blended learning is very common in classroom practice [6], [7]. Therefore, many researchers conduct a study regarding the use of blended learning including the impact and reasons behind the success of blended learning approach. First of all, a study shows that blended learning using Moodle is proven to be effective and efficient in helping the learning process [8], while Drotárová et al. [9] managed to find an effective blended learning model, especially for subjects that usually require direct practice (not just theoretical). Other researchers, Agosto et al. [10] prove that blogs as an online classroom media can be quite effective to utilize. Another research was conducted by Milic et al. in quasi experimental design also proves that students' competence improved significantly with the application of blended learning in the experimental class [11]. In line with the advantages that has been shown from the research above, this study wants to dig deeper on the use of blended learning especially in writing classroom. Writing activities that usually take more time can be challenging in offline classroom, therefore this study will explore more on the online writing activities and compared to the offline practice.

There are many facilities that can be used to support blended learning, which can be in the form of software such as netsupport school, netsupport manager, etc. in the form of web-based classroom, there are Edmodo, google classroom, classnote book, etc. In addition, there is also a web-based service in the form of a raw platform where the web managers can modify the web based on their creativity and innovation such as Moodle. According to Indra [12], online classes can be created with Content Management System (CMS) based services such as; moodle, Efront, ATutor, Dacebo, etc. In addition, many online classrooms are now available on cell phone, which makes it easier for the users in terms of service and user friendliness. Moodle-based online learning management system is quite common among academics. In Indonesia, for example, many universities use it as their e-learning platform, as well as the Indonesian government provides Moodle-based LMS called "Spada" which can be accessed by Indonesian lecturers and the students. Moodle itself functions as a virtual class or a substitute for face-to-face classes. According to Surjono [13], Moodle can be used to support the students to collaborate, do assignments and quizzes. Melfachrozi [14] states that e-learning using Moodle has several advantages such as fulfill the elements of online classes as a substitute for face-to-face classes; use simple IT technology; make it easy in terms of class and subject organization; have a good level of security; and provide many language choices.

From the explanation above, it can be said that Moodle can indeed be an alternative to online classes because of the facilities and service support that can replace face-to-face classes. As Evans et al. [7] say that blended learning can facilitate better for students learning needs. In relation to the learning process for certain subjects, such as in writing class for EFL learners, teachers may need to use other platform to combine such as google docs or coggle.it to facilitate more writing activities. Google docs is an online facility provided in Google Drive which can be accessed by all Gmail account owners. In teaching writing, for example, teachers can use Google docs to work collaboratively. It can be used as media instructional for students to write together, and give feedback each other. Therefore, with appropriate teaching strategy, teachers can facilitate students to learn better using both online learning platforms. In collaborative writing, for instance, students can be more active by giving mutual responses or comments on their friends' work [15]. So, by using google docs, students besides being writers, they also become readers and reviewers. This experience is expected to increase 
learning interaction and students can exchange knowledge and improve their writing competency better.

Started from the theoretical basis above, this research explored the use of blended learning in writing classroom. Some online platforms are used, such as moodle based learning management system, website at coggle.it., and google docs. Those facilities are utilized for online activities in experimental class.

\section{Research Method}

This research focuses on the extent to which the blended learning model can help students to improve their writing abilities. Before doing this research, the researcher used moodlebased online class where the activities were adjusted for writing. The learning process used writing approach includes: pre-writing, writing, revising, proofreading, and publishing. All of these activities are supported by online facilities available in online classes with the Moodle platform and combined with the use of google docs. To measure the effectiveness of this learning, the researcher used a quasi-experimental design where the researcher involved a control group and an experimental group to examine the causal relationship between the use of blended learning and the improvement of students' writing skills. Borg and Gall as cited in [16] state that experimental research is very appropriate when used to measure causal relationships. The experimental research itself aims to measure the effect of the independent variables on the dependent variable. After that, the comparison with the control class will be measured to determine the extent of the effectiveness of the treatment carried out. Here the researcher conducts trials under special conditions which are deliberately created to try out the methods or techniques. The reason the researcher used a quasi-experiment was the limited number of students who were used as research samples so that the research is carried out in one class, while the control class is a class that uses conventional learning.

The instruments in this study are: tests and field notes. Here the researcher conducted a written test that refers to the appropriate material for the level of the students. Firstly, it is started with a pre-test to find out the student's writing skills before being subjected to treatment. After the treatment is complete, each student was given a post-test to find out the difference before and after the treatment. Meanwhile, field notes are used to take a closer look at the factors that may support or hinder the learning process. The population in this study was he students of Universitas Hasyim Asy'ari Tebuireng Jombang in the department of Islamic Education at the Faculty of Islamic Studies consisting of 2 classes. The sample was taken from 2 classes of $3^{\text {rd }}$ semester students. The control class consisted of 38 students and the treatment class consisted of 35 students.

This research was conducted in 3 steps, namely pre-test, treatment and post-test. Initial data in this study were obtained from pre-test scores, while the final data were taken from post-test scores. Then after the data was collected, it was processed statistically including: finding the gain between pre-test and post-test; finding the mean of two variables; finding the squared of deviation; and finding the result of T-test. To gain deeper understanding of the process during the teaching learning activities, the researcher used a field note; it is expected to give more support of comprehensive data collection. 


\section{Results and Discussion}

There are several steps taken in this research before blended learning is applied to the research subject. Firstly, preparing the online class with moodle-based classroom. The next is organizing online classes in terms of the online material and several activities for the students. The last is enrolling the students to the online class. In the writing activities, the students used several online platforms beside the facilities provided in the moodle classroom, such as coggle.it for pre-writing activities and google docs in writing and editing process.

Based on the activities, it shows that using google docs have several benefits such as the majority of students are familiar with the Gmail account, which includes Google Docs facilities; the feature in coggle.it and google docs can suit the writing process including: prewriting, writing, editing, and proofreading. In addition, the students can collaborate online in writing, as well as provide feedback or comments on the work of other students asynchronously.

The learning process in the experimental class was carried out for 6 meetings started with a pre-test to measure the students' writing skills before being given treatment, while the control class was using conventional learning model. During the 6 weeks of the meeting, the researcher concluded that each learning model (conventional and blended learning) has its own advantages. The advantages in conventional learning include: Students can feel the learning atmosphere because of the direct interaction. In addition, the control over students in doing assignments could be better because it was supervised directly by the teacher. The weaknesses of the conventional method are: the limited time make students cannot optimally practice writing learning in the class. Meanwhile, in blended learning, students can have more flexible time to do it. In addition, with the "comments" feature in google docs, the need for the "editing" process in the writing learning process can be accommodated properly. It is in line with the finding of Evans et al. [7] proving the effectiveness of blended learning usage in learning management system. The interaction is built both between students and other students, as well as the students and the teachers.

After 6 meetings in the control class and the experimental class, at the end the students were given a posttest to measure their writing skills after the treatment was applied. From the comparison of scores obtained from the control class and treatment class, the N-Gain for the experimental class is 23.9649 and the control class is 28.4758 . From the $\mathrm{N}$-Gain which shows the mean below 40, it can be concluded that there is no significant difference between the conventional classroom method and the blended learning class. This can be caused by several factors, including: readiness of the students in using technology, and student awareness in learning and improving their writing skills or abilities. Even though students do a lot of activities online, the results of their work will be difficult to control, whether it is the work of their own or the results of others, or the help of an online dictionary. It is very common now to use software or web help to translate Indonesian to English or vice versa. In this case, conventional classes are superior in terms of controlling the originality of student work.

This is in line with the results of the T-test, which shows that the use of the blended learning model does not show a significant comparison with conventional activities. The results of the T-test show the value at sig. 2 tailed above 0.05 , it can be concluded that there is no significant difference from the comparison of the 2 classes between the experimental class and the control class.

However, if the analysis is done per class it shows that the students' scores in writing have increased. So it can be concluded that the writing process approach used in writing learning is able to help students improve their writing skills. As Vaughan et al. [17] say that the success 
of what is learned is inseparable from the way it is learned. Even though the result of blended learning implementation may not have significant influence if compared to conventional classroom, the improvement of the students' writing ability show significant increase from pretest to posttest.

More analysis from the results of the T-test shows that the sig. 2 tailed value is below 0.05 , which shows that there is a significant difference between before and after treatment in each of these classes. Based on the findings above that between blended learning and conventional classroom do not have significant different result in writing classroom, it can be concluded that that the use of blended learning may be an alternative way in teaching. However, to find the effectiveness of both may need more studies.

Other factor that may impact the result of this blended learning treatment is the students' digital literacy. based on the data from the field notes, it is found that some students are very low in digital literacy. Some students who lived in Islamic dormitory around the campus have limited time to access their gadget. This condition may affect students' digital literacy because they are not very familiar with ICT. Ibrahim \& Nat [18] say that how the users of blended learning interact with technology may affect the result of the teaching learning. In addition, some students are struggling face difficulties regarding the internet connection. When the teacher conducted video call, for example, some students were getting difficulties to join because of the internet technical issues, while online interaction between teachers and students is considered as an important factor for students' success in blended learning [19].

Another issue is related to the institution's policy. Some students are quite surprised with the blended learning model because there are no facilities provided by the institution to deal with online learning. During an interview in the early meeting, most of the students never practice online learning and do not know blended learning practice. Some students were questioning why they have to study online in some meetings. This is something new for them and it takes time to adapt. For example, during three weeks to start the class, it was found that some students forgot their username or password to login. It shows that students' awareness in ICT is still low. Therefore, the role of the institution in supporting the use of ICT is very important. This is considered as one key factor in students learning success [20].

Alammary et al. [6] suggest teachers when they implement blended learning to conduct from low-impact (only few online activities) then medium impact before it gets the high impact practice (more online activities) depending on the teachers ability in ICT. In this case, the teacher has quite competence in ICT for teaching learning and has implemented the use of e-learning platform for two years. Therefore the teacher used medium impact approach during the blended learning process. However, it was found that many students had low digital literacy, and some of them had limited access to gadget usage. This may give another view of the need of ICT competence that not only the teachers but also the students need to have an ample competence in ICT blended learning is used. Therefore, the readiness of digital literacy can be high consideration before applying blended learning or online learning.

\section{Conclusion}

In this study, the use of blended learning compared to conventional methods in writing classes does not show a significant difference. However, the data per class shows an increase in writing scores in each class which shows the learning method applied to the 2 classes can be said to be effective, namely the writing process approach. In other words, blended learning can be an alternative model in teaching learning process. Regarding the limitations found during 
the process of teaching learning such as, students' digital literacy, students' access on the internet, and the institution policy on ICT practice of the academics, it is considered that those aspects need to be considered for teachers before applying online or blended learning in classroom practice. This may impact on the students learning progress, or hinder their advance depending on the extent the issues can be tackled. Therefore, future research may be necessarily important to conduct deeper studies with more varied research subjects to obtain a better picture of the effectiveness of using online or blended learning classes.

\section{References}

[1] X. V. Wu, Y. S. Chan, K. H. S. Tan, and W. Wang, "A systematic review of online learning programs for nurse preceptors," Nurse Educ. Today, vol. 60, pp. 11-22, 2018.

[2] Kompas, “Blended Learning', Membangun Ruang Belajar 'Zaman Now' Menyenangkan,” 2020. https://www.kompas.com/edu/read/2020/07/09/110818371/blended-learningmembangun-ruang-belajar-zaman-now-menyenangkan?page=all (accessed Aug. 21, 2020).

[3] D. R. Garrison and N. D. Vaughan, Blended learning in higher education: Framework, principles, and guidelines. John Wiley \& Sons, 2008.

[4] A. Littlejohn and C. Pegler, Preparing for blended e-learning. Routledge, 2007.

[5] J. MacDonald, Blended learning and online tutoring: Planning learner support and activity design. Gower Publishing, Ltd., 2008.

[6] A. Alammary, J. Sheard, and A. Carbone, "Blended learning in higher education: Three different design approaches," Australas. J. Educ. Technol., vol. 30, no. 4, 2014.

[7] J. C. Evans, H. Yip, K. Chan, C. Armatas, and A. Tse, "Blended learning in higher education: professional development in a Hong Kong university," High. Educ. Res. Dev., vol. 39, no. 4, pp. 643-656, 2020.

[8] M. Ari and F. Arslan, "Web-Based Blended E-Learning Studies in Distance Education: A Case Study," Int. J. Arts Sci., vol. 4, no. 21, pp. 329-343, 2011, [Online]. Available: https://search.proquest.com/docview/1315166542?accountid=62692.

[9] J. Drotárová, D. Kačíková, M. Kelemen, and M. Bodor, "The Possibilities of Using Blended Learning in Fire Safety Education," in CBU International Conference Proceedings..., 2016, vol. 4, p. 283.

[10] D. E. Agosto, A. J. Copeland, and L. Zach, "Testing the Benefits of Blended Education: Using Social Technology to Foster Collaboration and Knowledge Sharing in Face-To-Face LIS Courses,” J. Educ. Libr. Inf. Sci., vol. 54, no. 2, pp. 94-107, 2013, [Online]. Available: https://search.proquest.com/docview/1399142292? accountid=62692.

[11] N. M. Milic et al., "Improving Education in Medical Statistics: Implementing a Blended Learning Model in the Existing Curriculum," PLoS One, vol. 11, no. 2, 2016, doi: http://dx.doi.org/10.1371/journal.pone.0148882.

[12] S. Indra, "7 CMS Untuk Membuat E-Learning," vol. 2017, no. September 09. 2013, [Online]. Available: http://tugaselesai.blogspot.com/2013/03/7-cms-untuk-membuat-elearning_27.html.

[13] H. D. Surjono, "Membangun E-Learning dengan Moodle ." 2009, [Online]. Available: http://blog.uny.ac.id/hermansurjono.

[14] M. Melfachrozi, "Penggunaan Aplikasi E-Learning (Moodle)." 2006, [Online]. Available: http://repo.unand.ac.id/3208/1/rozie-moodle.pdf. 
[15] A. Bahar, "Tekno Guru : Yuk Manfaatkan Fitur Google Docs dalam Latihan Menulis Kolaboratif di Kelas,” vol. 2018, no. 10 September 2018. 2016, [Online]. Available: http://www.ahzaa.net/2016/09/tekno-guru-yuk-manfaatkan-fitur-google.html.

[16] M. A. Latief, Research Methods on Language Learning an Introduction, 2nd ed. Malang: UM Press, 2016.

[17] N. D. Vaughan, M. Cleveland-Innes, and D. R. Garrison, Teaching in blended learning environments: Creating and sustaining communities of inquiry. Athabasca University Press, 2013.

[18] M. M. Ibrahim and M. Nat, "Blended learning motivation model for instructors in higher education institutions," Int. J. Educ. Technol. High. Educ., vol. 16, no. 1, p. 12, 2019.

[19] H. K. Allan, "Blended Learning in Higher Education: An Exploration of Teaching Approaches."

[20] W. W. Porter, C. R. Graham, K. A. Spring, and K. R. Welch, "Blended learning in higher education: Institutional adoption and implementation," Comput. Educ., vol. 75, pp. 185-195, 2014. 